\title{
Peduli Banjir Desa Karangligar Karawang Sebagai Bentuk Kepedulian Sosial Mahasiswa
}

\author{
Devi Sulaeman', Dede Sugandi ${ }^{2}$, Herdian Kertayasa ${ }^{3}$, Gina Kania ${ }^{4}$, Dede Ajeng Arini ${ }^{5}$, \\ Teti Ernawati ${ }^{6}$ \\ ${ }^{1,4}$ Prodi PIAUD, STIT Rakeyan Santang Karawang \\ 2,3,5,6 Prodi PGMI, STIT Rakeyan Santang Karawang \\ email: devisulaeman@gmail.com
}

\begin{abstract}
The purpose of devotion This community is to provide moral and material encouragement through social activities to the people of Karangligar Village who were affected by the floods and to provide social education to the wider community to participate in social care for fellow children of the nation. Community social activities carried out by STIT students Rakeyan Santang are based on a sense of concern for problems experienced by people who need assistance, especially for basic needs. With the presence of the community service team and students at the location, it has a very positive influence on the community through activities carried out such as fundraising, collecting aid and distributing basic food aid that can benefit the community so that it is welcomed by the village government and residents. The results of this social activity are expected to be able to alleviate the difficulties of Karangligar residents who are affected by flooding, reduce social and environmental problems, especially in the Karawang Regency area. The implication of the flood care activities of STIT Rakeyan Santang students can strengthen brotherhood, the spirit of mutual cooperation, foster togetherness in order to maintain a harmonious social life and provide information for the government to anticipate disasters in the future.
\end{abstract}

Keywords: Flood Care, Social Community, Social Care

\begin{abstract}
Abstrak
Tujuan dari pengabdian masyarakat ini adalah memberi dorongan secara moral dan materi melalui kegiatan sosial kepada masyarakat Desa Karangligar yang terdampak banjir dan memberikan edukasi sosial masyarakat luas untuk ikut berpartisipasi dalam kepedulian sosial sesama anak bangsa. Kegiatan sosial kemasyarakatan yang dilakukan oleh mahasiswa STIT Rakeyan Santang didasarkan pada rasa kepedulian terhadap masalah yang dialami oleh masyarakat yang membutuhkan bantuan tertutama akan kebutuhan pokok. Dengan hadirnya tim pengabdian dan mahasiswa di lokasi sangat membawa pengaruh positif kepada masyarakat melalui kegiatan yang dilakukan seperti penggalangan dana, penghimpunan bantuan dan pendistribusian bantuan sembako yang dapat bermanfaat bagi masyarakat sehingga disambut baik oleh pemerintah desa maupun warga. Hasil dari kegiatan sosial ini diharapkan mampu meringankan kesulitan warga Karangligar yang terdampak banjir, mengurangi masalah sosial dan lingkungan khususnya Daerah Kabupaten Karawang. Implikasi dari kegiatan peduli banjir mahasiswa STIT Rakeyan Santang dapat memperkuat persaudaraan, semangat gotong royong, memupuk kebersamaan demi menjaga kehidupan sosial masyarakat yang harmonis serta memberikan informasi bagi pemerintah untuk antisipasi bencana ke depannya.
\end{abstract}

Kata Kunci: Peduli Banjir, Sosial Kemasyarakatan, Kepedulian Sosial 
PENDAHULUAN

$\begin{array}{lcr}\text { Tridharma } & \text { adalah } & \text { kewajiban } \\ \text { Perguruan } & \text { Tinggi } & \text { untuk } \\ \text { menyelenggarakan Pendidikan, Penelitian, } & \\ \text { dan Pengabdian } & \text { Kepada } & \text { Masyarakat }\end{array}$
(Wibawa, 2017). Mahasiswa sebagai bagian dari Perguruan Tinggi diharapkan dapat melaksanakan kegiatan-kegiatan yang merepresentasikan Tri Dharma Perguran Tinggi tersebut. Sebagai salah satu bentuk dari pelaksanaan Tri Dharma Perguruan Tinggi yaitu dengan melaksankan kegiatan-kegiatan yang bersifat sosial-kemasyarakatan.

Kepedulian sosial merupakan bentuk keseimbangan ibadah kepada Allah SWT sebagai wujud ibadah ritual (mahdlah) dengan ibadah sosial (ghair mahdlah). Bentuk kongkritnya ialah melakukan perbuatan baik (ihsan) dengan cara memberikan perhatian dan bantuanbantuan ekonomi kepada mereka yang yang berhak menerimanya (Anwar, 2015). Impelementasi kepedulian sosial merupakan salah satu bentuk wujud keimanan kepada Allah SWT. Ketika manusia mengaku beriman bahkan rajin mengerjakan ibadah mahdhah-shalat misalnya namun tidak memiliki kepedulian sosial, maka pengakuan tersebut tidak bermakna. Kepedulian sosial merupakan salah satu bentuk amal saleh. Al-Quran banyak menggandengkan katakata amanu dengan wa 'amilu al-shalihat. Keduanya bagaikan dua sisi mata uang yang tidak dapat dipisahkan. Satu sama lain harus terintegrasi.

Kabupaten Karawang merupakan salah satu wilayah yang rawan akan bencana banjir. Hal ini sebagai mana disampaikan oleh Badan Penanggulangan Bencana Daerah (BPBD) memetakan wilayah Karawang yang rawan bencana, termasuk banjir. Banjir menjadi bencana rutin yang selalu terjadi setiap musim hujan di Karawang. BPBD meminta satgas untuk melakukan pemantauan lebih detil. BPBD mencatat, 26 kecamatan masuk wilayah rawan banjir (Radar Karawang, n.d.)

Desa Karangligar adalah salah satu daerah di Wilayah Kabupaten Karawang yang sering menjadi langganan Banjir. Hal ini dikarenakan daerah tersebut merupakan titik pertemuan antara Sungai Cibeet dan Sungai Citarum, belum lagi saat itu merupakan musim penghujan sehingga warga sekitar Desa Karangligar sudah pasti akan sering terdampak banjir. Curah hujan yang tinggi membuat luapan Sungai Citarum dan Sungai Cibeet merendam kawasan itu (Kompas.com, 2021).

Manusia sebagai makhluk sosial tentunya tidak bisa hidup sendiri, melainkan harus saling membantu dan tolong-menolong dengan sesamanya. Kegiatan-kegiatan yang mencerminkan kepedulian sosial perlu dilaksanakan oleh para Mahasiswa sebagai bentuk dari pengabdian dan kepedulian sosial terhadap sesama.

Mengingat keberadaan STIT Rakeyan Santang berlokasi di Kabupaten Karawang, sudah selayaknya dapat menujukkan rasa kepedulian sosial terhadap para korban yang terdampak banjir. Maka mahasiswa STIT Rakeyan Santang Karawang peduli bergerak mengadakan aksi pelayanan dan bakti sosial. Tujuan dari kegiatan ini untuk meringankan beban masyarakat yang mengalami terdampak banjir dan mengajak masyarakat umum untuk bersama dalam meningkatkan kepedulian terhadap korban banjir.

Kegiatan sosial yang dilakukan oleh mahasiswa STIT Rakeyan Santang Karawang merupakan salah satu wujud kepedulian terhadap masyarakat. Kegiatan ini tidak mudah untuk dilaksanakan karena dilakukan dimasa pandemi, tetapi demi rasa kepedulian para mahasiswa tetap melakukannya dengan mengikuti protokol kesehatan. Melihat hal ini bahwa partisipasi dari masyarakat sangat berperan penting dan paling efektif dalam mensukseskan upaya penanggulangan 
banjir, karena masyarakat sendirilah yang paling tahu kebutuhan mereka (Imamsari \& Triastuti, 2017).

Tujuan dari kegiatan sosial ini adalah memberi dukungan secara moral, memberikan alat kesehatan dan obatobatan, paket sembako serta bantuan berupa keperluan sandang dan pangan pada warga masyarakat yang terkena dampak banjir. Targetnya dalam kegiatan sosial ini adalah masyarakat yang mengalami musibah dapat bangkit seperti biasa serta beraktivitas seperti semula.

Dengan tercapainya target tersebut maka permasalahan yang dialami oleh masyarakat Desa Karangligar Kabupaten Karawang dapat teratasi dengan baik. Dengan melihat hal-hal seperti itu, maka tujuan dari kegiatan pengabdian masyarakat ini adalah memberi penguatan sosial, dorongan secara moral dan lewat pemberian kebutuhan pokok dan bakti sosial kepada masyarakat yang mengalami musibah banjir. Implikasi dari kegiatan pengabdian masyarakat ini: 1) mengurangi beban masyarakat Desa Karangligar yang terdampak banjir, 2) ikut serta dalam meningkatkan kepedulian sosial, 3) memberikam sumbangsih bagi masyarakat untuk mau berkontribusi dalam kegiatan sosial kemasyarakatan.

\section{METODE PENGABDIAN}

Metode dalam penulisan artikel ini adalah metode kualitatif. Menurut Sugiyono mentakan bahwa metode penelitian kualitatif tidak menggunakan populasi karena tipe penelitian kualitatif ini berangkat dari kasus tertentu yang ada pada situasi sosial tertentu dan hasil kajiannya tidak akan digeneralisasikan ke populasi, sedangkan untuk penelitian kuantitatif menggunakan populasi atau sampel (Sugiyono, 2015). Selanjutnya metode kualitatif adalah jenis penelitian yang temuan-temuannya tidak diperoleh melalui prosedur statistik atau bentuk hitungan lainnya (angka), melainkan dari data-data yag diperoleh dan yang dikumpulkan dengan mempergunakan beberapa pilihan sarana seperti wawancara, dokumen, buku, kaset vidio, foto-foto dan data sensus (Spencer et al., 2003). Metode pendekatan yang digunakan dalam penelitian ini adalah sosiologis. Dalam hal ini pembahasan lebih difokuskan pada penyelenggaraan kegiatan sosial. Informasi yang didapatkan dalam pengabdian ini didapat dari masyarakat umum dan media elektronik. Spesifikasi dari penelitian ini adalah deskriptif, dimana penelitian ini dapat menggambarkan suatu keadaan objek. Penelitian deskriptif adalah suatu metode penelitian yang dilakukan dengan tujuan utama untuk membuat gambaran atau mendeskripsikan tentang suatu keadaan secara objektif (Notoatmodjo, 2005).

Berdasarkan informasi dan kejadian di lapangan maka mahasiswa STIT Rakeyan Santang membuat suatu kegiatan sebagai sasaran. Sasaran pelaksanaan kegiatan ini masyarakat korban banjir yang ada di Desa Karangligar dan sekitarnya. Dukungan dan kepedulian yang diberikan mahasiswa STIT Rakeyan Santang dapat memberikan dampak positif. Selain itu harapannya, dengan terlaksananya kegiatan sosial ini, masyarakat dapat terbantu walaupun tidak dalam jumlah yang besar tetapi kegiatan ini bisa meringankan beban bagi masyarakat.

Kegiatan pengabdian masyarakat ini dilaksanakan pada tanggal 30 Januari -7 Februari 2021 di wilayah Desa Karangligar Kecamatan Telukjambe Barat Kabupaten Karawang. Metode pelaksanaan dilakukan dengan beberapa tahapan diantaranya: a) tahapan persiapan, melakukan sosialiasi yaitu mengadakan rapat persiapan yang dihadiri oleh unsur BEM, Hima-Prodi, perwakilan kelas, ORMAWA dan aktivis mahasiswa. Tahap berikutnya melaksanakan kegiatan penggalangan dana dengan mendatangi setiap kelas dari Prodi PIAUD dan PGMI, berkeliling di tempat wilayah masingmasing mahasiswa, memberikan proposal kepada lembaga-lembaga, dan di tempat 
umum masyarakat dengan menjaga protokol kesehatan, b) mengumpulkan dan menghimpun dana sumbangan sosial dan barang-barang yang bermanfaat dari para relawan yang kemudian dikemas dalam bentuk sembako, c) pendistribusian langsung ke lapangan Desa Karangligar, dengan berkomunikasi langsung dengan korban bencana banjir lebih mengetahui akan kebutuhuan bantuan, seperti popok bayi, makanan instan, obat-obatan, pakaian layak, sehingga penyaluran bantuan sosial tepat terhadap warga, serta memberikan dorongan moral sosial (support) untuk bersama gotong royong dalam membenahi banjir sebagai perwujudan kepedulian sosial.

Setelah kegiatan ini dilakukan maka mahasiswa melakukan evaluasi. Evaluasi ini bertujuan untuk mengukur keberhasilan dalam melaksanakan seluruh kegiatan. Salah satu cara mengukurnya adalah mendata kembali bantuan yang terkumpul agar pendistribusian dari para donatur maupun relawan dapat tersalurkan secara tepat dan menyeluruh bagi warga yang terdampak banjir.

Aktivitas yang dilakukan oleh mahasiswa STIT Rakeyan Santang disambut baik oleh beberapa unsur pemerintah setempat, diantaranya oleh perwakilan Desa Karangligar dan Tim Posko Penanggulangan Banjir dari warga setempat. Dalam sambutan tersebut, mereka sangat berterimakasih kepada mahasiswa dan Civitas Akademik Sekolah Tinggi Ilmu Tarbiyah (STIT) Rakeyan Santang Karawang atas kepedulian sosial dan dukungannya secara moral maupun materi kepada masyarakat yang mengalami musibah banjir.

\section{HASIL DAN PEMBAHASAN}

Kegiatan pengabdian masyarakat dengan kegiatan sosial dilaksanakan selama 9 Hari dari tanggal 30 Januari - 7 Februari 2021. Ada beberapa hal yang dilakukan oleh tim pengabdian masyarakat, sebagai berikut:
1. Rapat Koordinasi persiapan ke lokasi banjir

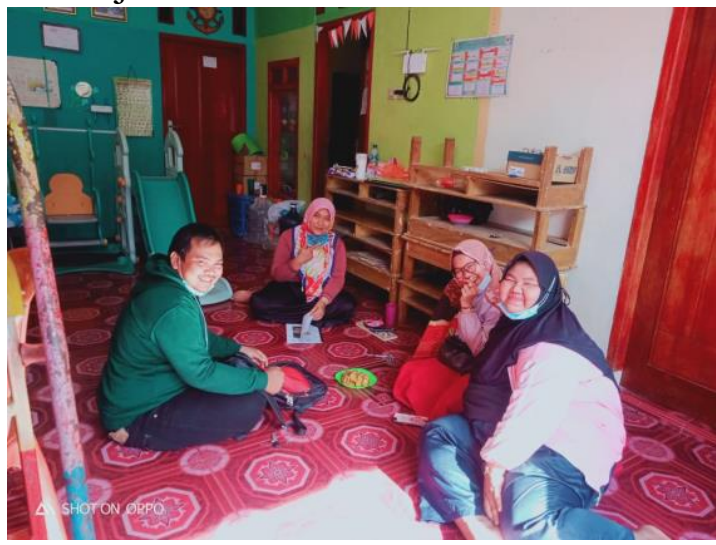

Gambar 1. Rapat persiapan pelaksanaan kegiatan sosial peduli banjir

Dalam rapat persiapan dapat ditentukan target yang akan dicapai seperti jumlah bantuan, alokasi biaya serta berkoordinasi dengan pihak kampus agar acara pengabdian ini dapat terarah dan tersalurkan dengan baik.

2. Penggalangan dana untuk korban banjir Desa Kalisari dan sekitarnya

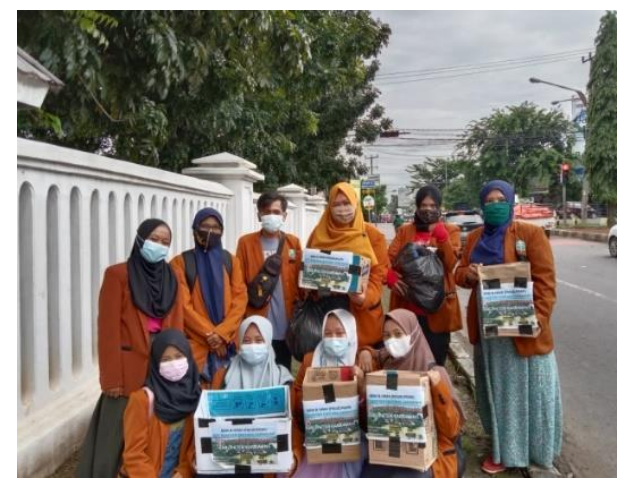

Gambar 2. Mengajak para masyarakat lain untuk ikut peduli banjir

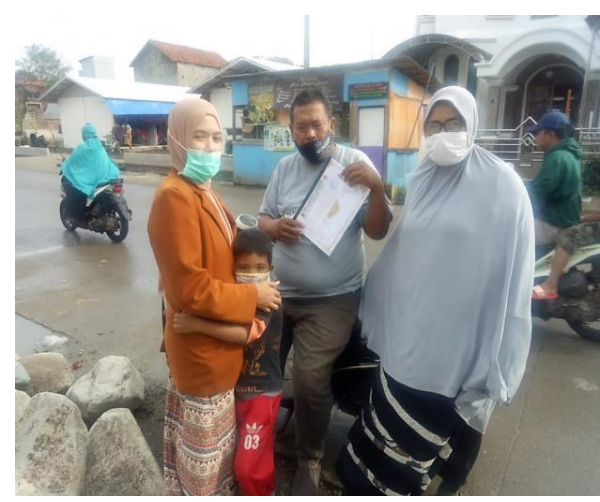

Gambar 3. Para pengguna jalan ikut serta memberikan donasi 
Dengan prinsip gotong royong mahasiswa STIT Rakeyan Santang mengajak semua masyarakat untuk ikut peduli terhadap korban banjir sehingga memberikan Tarbiyah (Pendidikan/pembinaan) dan edukasi sosial bagi masyarakat luas tentang tolong-menolong terhadap sesama.

3. Pendistribusian bantuan banjir

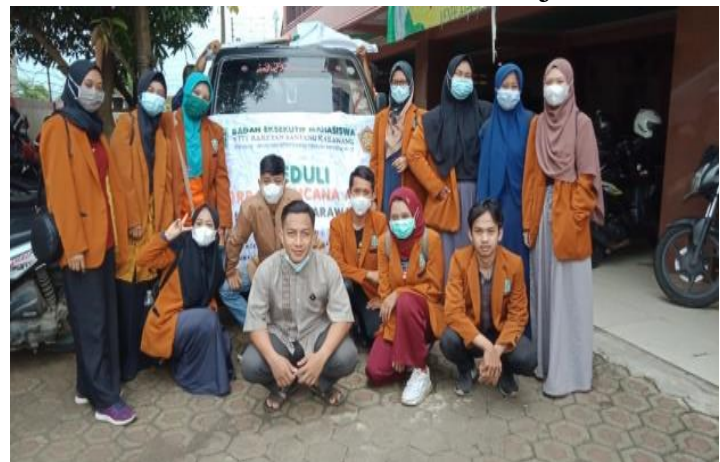

Gambar 4. Persiapan dan cek kelengkapan

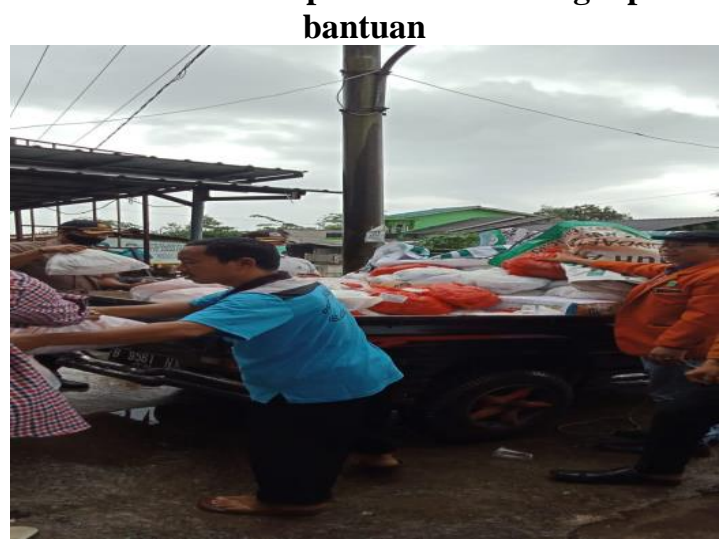

Gambar 5. Mobil pengangkut sembako tiba di lokasi banjir

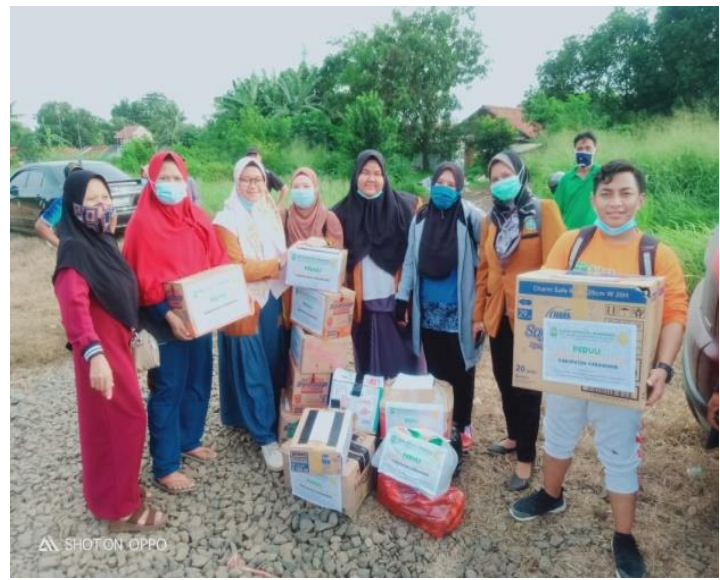

Gambar 6. Mahasiswa STIT Rakeyan Santang meninjau langsung di wilayah terdampak banjir

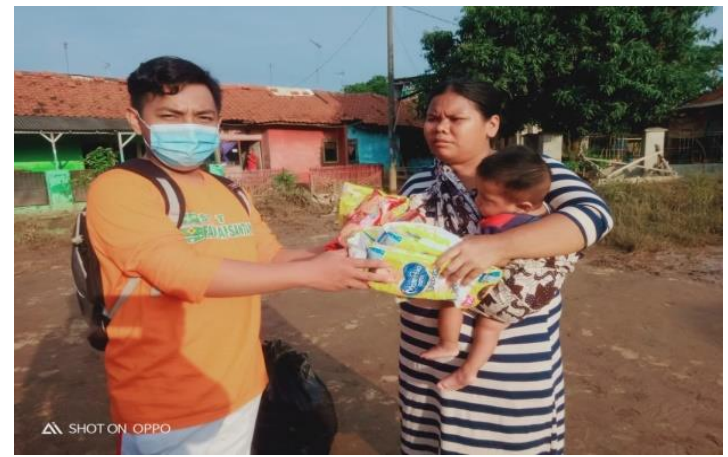

Gambar 7. Pemberian popok bayi sebagai bentuk kepedulian sosial

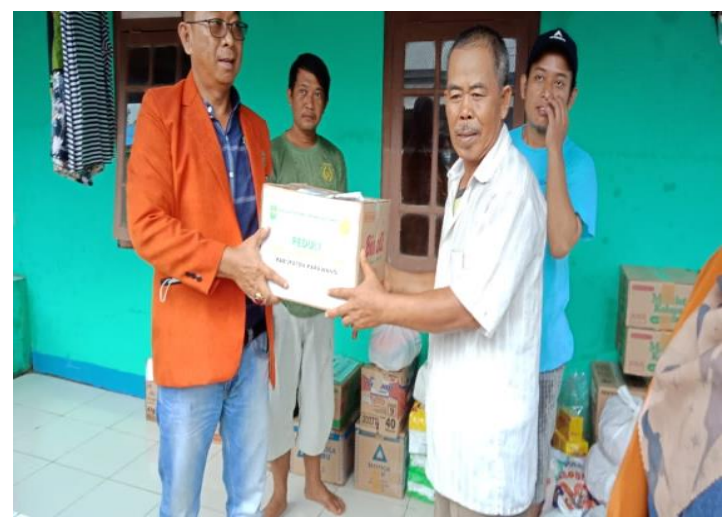

Gambar 8. Pemberian sembako dan kebutuhan pokok sangat berarti bagi warga yang terdampak banjir

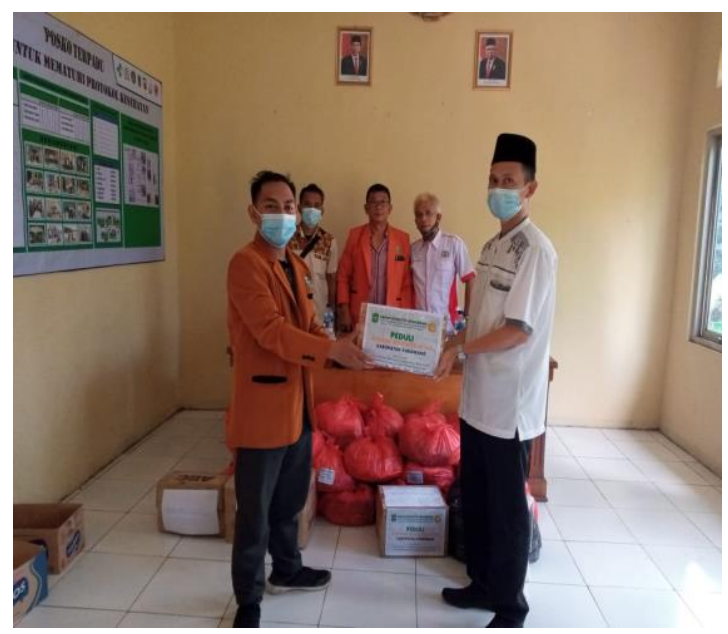

Gambar 9. Mahasiswa dan Tim Pengabdian disambut baik oleh Perwakilan Desa dan Tim Posko Bencana Banjir

Pendistribusian dan pembagian sembako ini salah satu bukti rasa kepadulian sosial kepada warga yang kehilangan barang-barang berharga pasca banjir. Selain itu untuk meringankan beban mereka dalam menghadapi musibah ini. Warga yang telah kehilangan harta benda, 
alat-alat rumah tangga lebih lagi kebutuhan pokok untuk bertahan hidup sehingga mereka sangat membutuhkan dukungan dari semua pihak. Itu sebabnya para tim pengabdian dan mahasiswa STIT Rakeyan Santang Karawang mengupayakan untuk menjadi kaki tangan bagi warga untuk menyalurkan sembako dan bantuan tersebut. Wujud rasa kepedulian sosial ini tidak terlepas akan kesadaran hidup berdampingan sesama anak bangsa. Pengabdian masyarakat dengan prinsip menolong sesama dan lebih membutuhkan dalam kegiatan sosial merupakan bentuk nyata untuk mewujudkan persaudaraan yang kuat. Kegiatan sosial ataupun bakti sosial merupakan suatu kegiatan wujud dari kepedulian atau rasa kemanusiaan terhadap sesama manusia. Dimana dengan adanya kegiatan ini kita dapat merekatkan rasa kekerabatan kita terhadap orang lain. Kata sosial didalamnya tercakup perorangan dan kelompok-kelompok (Tambunan et al., 2020). Selain itu, kegiatan sosial ini sangat berarti kepada masyarakat karena merasa diperhatikan ditengah-tengah kesulitan yang sedang mereka alami.

Dengan kegitan sosial yang dilakukan oleh Tim Pengabdian masyarakat dan mahasiswa STIT Rakeyan Santang memberikan efek positif bagi warga yang terdampak banjir khusunya warga Desa Karangligar Karawang yang wilayahnya parah terkena bencana banjir. Sehingga mengurangi beban mereka dengan memberikan bantuan sosial dan pemberian akan kebutuhan pokok. Selain itu implikasi dari kegiatan ini adalah memberikan edukasi sosial terhadap masyarakat umum untuk meningkatkan rasa kepedulian sesama. Hal ini selaras dengan amanat UU Nomor 24 tahun 2007 bahwa mewajibkan seluruh warga negara untuk berperan serta dalam tindak penanggulangan bencana dengan peran aktif mereka masing-masing yang berupa: a) menjaga kehidupan sosial masyarakat yang harmonis, memelihara keseimbangan, keserasian, keselarasan, dan kelestarian fungsi lingkungan hidup; b) melakukan kegiatan penanggulangan bencana; dan c) memberikan informasi yang benar kepada publik tentang penanggulangan bencana (UU Nomor 24 Tahun 2007, n.d.).

Dengan demikian kegiatan sosial mahasiswa STIT Rakeyan Santang untuk pengabdian masyarakat yang terdampak banjir Desa Kalisari Karawang merupakan perwujudan gerakan kemanusian serta dukungan sosial untuk ikut serta membantu kesejahteraan masyarakat yang terdampak banjir.

\section{SIMPULAN}

Kegiatan sosial kemasyarakatan mahasiswa STIT Rakeyan Santang terhadap warga terdampak banjir Desa Karangligar di Kabupaten Karawang telah berjalan dengan baik sesuai dengan tujuan dari pengabdian masyarakat. Hasil kegiatan dari pengabdian masyarakat ini telah memberikan efek positif, yakni meringankan beban masyarakat yang terdampak bencana banjir dengan menyalurkan bantuan kebutuhan pokok dan mengajak masyarakat luas untuk ikut berpartisipasi dalam kepedulian sosial sesama anak bangsa. Sekalipun hasil ini masih belum sempurna, karena warga masih membutuhkan dukungan selanjutnya yang dapat memulihkan pasca banjir.

Dengan kegiatan sosial tersebut diharapkan memupuk rasa persaudaran sebagai anak bangsa yang berpegang teguh semangat kebersamaan dan gotong royong. Inisiatif dari tim pengabdian masyarakat STIT Rakeyan Santang Karawang ini sangat patut diapresiasi dan didukung penuh oleh para pimpinan dan dosen yang tergabung dalam tim pengabdian masyarakat dengan melakukan pendampingan sehingga kegiatan sosial ini dapat terlaksana dengan baik. 


\section{DAFTAR PUSTAKA}

[1.] Anwar, C. (2015). TAfsir Ayat-Ayat Ekonomi, Kepemimpinan Dan Kemasyarakatan. UIN Bandung Press.

[2.] Imamsari, F. S., \& Triastuti, R. (2017). Partisipasi Masyarakat pada Penanggulangan Banjir dalam Perspektif Pendidikan Kewarganegaraan. Educitizen, 2(1).

[3.] Kompas.com. (2021). Warga Desa Karangligar Karawang Mengungsi Akibat Banjir. https://foto.kompas.com/photo/read/2 021/2/10/1612951070b0e/1/wargadesa-karangligar-karawangmengungsi-akibat-banjir.

[4.] Notoatmodjo, S. (2005). Metodologi Penelitian Kesehatan. Cetakan ketiga. Jakarta. PT. Rineka Cipta.

[5.] Radar Karawang. (n.d.). 26 Kecamatan Rawan Banjir. https://radarkarawang.id/metropolis/2 6-kecamatan-rawan-banjir/

[6.] Spencer, L., Ritchie, J., \& O’Connor, W. (2003). Analysis: practices, principles and processes. In Qualitative research practice: A guide for social science students and researchers (Vol. 199).

[7.] Sugiyono, P. (2015). Metode penelitian kombinasi (mixed methods). In Bandung: Alfabeta (Vol. 28)

[8.] Tambunan, E., Purba, M. L., \& Haloho, E. (2020). PENDAmpingan Gerakan Bakti Sosial Berbagi Paket Sembako Peduli Covid-19 Hima Manajemen Universitas Sari Mutiara Indonesia. Jurnal Abdimas Mutiara, 1(2), 58-63.

[9.] UU Nomor 24 Tahun 2007. (n.d.). https://bnpb.go.id/ppid/file/UU_24_2 007

[10.] Wibawa, S. (2017). Tridharma
Perguruan Tinggi (Pendidikan Dan Pengabdian Kepada Masyarakat). Disampaikan Dalam Rapat Perencanaan Pengawasan Proses Bisnis Perguruan Tinggi Negeri. Yogyakarta, 29, 1-15. 